\title{
The Effect of Pregnancy Exercises on the Sleep Quality of Pregnant Women in the Third Trimester of Ulaweng Health Center Work Area, Bone Regency
}

\author{
Indryani $^{1}$, Mustar $^{2}$ \\ ${ }^{1}$ Institut Sains Dan Kesehatan Bone ${ }^{2}$ Institut Sains Dan Kesehatan \\ Corresponding Author: Indryani
}

\begin{abstract}
Sleep disorder is one of the most common complaints experienced by pregnant women in the third trimester, sleep disorders have an impact on the condition of pregnant women and fetuses which cause a decrease in immunity that improves the risks of some diseases that will endanger the condition of the fetus and the risk of premature delivery and Caesar surgery. Pregnancy exercise is one of the basic needs in sport that is recommended during pregnancy. Pregnancy exercise is expected to reduce complications that occur during pregnancy, because it has the benefit in training breathing and strengthening the pelvic muscles. This study aims at determining the effect of pregnancy exercise on improving the sleep quality of pregnant women in the third trimester. This type of research is a pre-experimental one group pretest and posttest with a research design using a quantitative approach. Based on the results of statistical tests through the Wilcoxon signed ranks test that the exact sig value. (2-tailed) and asymp. sig. (2-tailed) or $\mathrm{p}=0.03<0.05$ so it can be concluded that pregnancy exercise affects the sleep quality of pregnant women in the third trimester. It is recommended to health workers, especially midwives, to conduct more intensive counseling, especially counseling about the benefits of doing pregnancy exercises, especially in the third trimester of pregnancy to provide a sense of comfort to pregnant women and to prevent complications in pregnancy to reduce the cases of maternal and infant mortality rates during pregnancy at Bone District.
\end{abstract}

Keywords: Pregnant Women, Pregnancy Exercises, Sleep Quality

\section{INTRODUCTION}

Sleep disorder is one of the most common complaints conveyed by pregnant women in the third trimester, sleep disorders have an impact on the condition of pregnant women and fetuses which cause a decrease in immunity so that the mother is susceptible to disease and to harm the condition of the fetus and improve the risk of premature delivery and caesarean section. Pregnancy exercise is one of the basic needs in sport that is recommended during pregnancy, with pregnancy exercise it is expected to reduce complications that occur during pregnancy, because it has benefit of training breathing and strengthening the pelvic muscles (Pithaloka 2020)

The impact of sleep patterns disorder that occurs for a long time during pregnancy can cause low birth weight babies, imbalanced neurodevelopment, premature birth and a weakened immune system in infants (Okun, Schetter, and Glynn 2011). Pregnancy is a natural process; if it is not managed properly, it will give complications to the healthy and safe condition of mother and fetus. Philosophy is a statement about beliefs and values that influence the behavior of a person/group, Philosophy of pregnancy care describes the beliefs held by midwives and is used as a 
guide that is believed to provide midwifery care to clients during pregnancy, third trimester of pregnancy pregnant women need adequate supplies energy, in addition to overcoming the increasingly heavy burden, as well as energy reserves for welcoming childbirth (Elisabeth Siwi Walyani 2015)

Most pregnant women have experience in sleep disorders which can be caused by physiological changes in pregnancy that can lead to pathological things for pregnant women which can cause various complaints and sleep disorders (Venkata C. and Venkatashiah S. B. 2009)

The maternal mortality rate is still quite high. According to WHO (Word Health Organization), 1400 women die every day or more than 500,000 women die every year due to pregnancy and childbirth. Pregnancy exercise has a big role in the process of pregnancy and childbirth. One of the benefits is that pregnant women who do pregnancy exercise for about 3-5 hours each week have a smaller chance of giving birth prematurely than those who do not do pregnancy exercise. The United Nations International emergency found states that every year nearly 10,000 women die because of pregnancy problems and childbirth (WHO 2017)

According to the South Sulawesi Health Office, the number of maternal deaths in 2017 reached 115 cases, while infant mortality reached 1,059 cases. These cases of death are often found in General Hospitals (RSU) with a percentage of $79.13 \%$ or as many as 91 cases. Then it happened at home with 9 cases or about $7.83 \%$, then found in the Public Health Centre with 7 cases or $6.08 \%$, on the street 5 cases or $4.35 \%$, at the Unit of Public Health Centre 2 cases or $1.74 \%$ and the maternity home 1 cases or $0.87 \%$ (South Sulawesi Provincial Health Office 2015)

The biggest cause of maternal death during 2010-2013 and even now remains the same, namely bleeding, while long process in childbirth is the lowest contributor to death. Meanwhile, other complications of pregnancy and childbirth also play a significant role in causing maternal death. (Ministry of Health 2014)

Based on the data above, the high maternal mortality rate caused by various complications of pregnancy and childbirth, researchers are interested in finding alternatives to prevent maternal mortality cases by conducting a study entitled the effect of pregnancy exercise on the quality of sleep of pregnant women in the third trimester of pregnancy.

\section{LITERATURE REVIEW}

Pregnancy is a continuous chain that starts from the ovulation process, ovulation is the process of conception of the ovum by sperm, after ovulation occurs the fertilization process is the fusion of the ovum and sperm after fertilization occurs the process of attaching the fertilization results to the endometrial wall which is called implantation. After the implantation process, the final stage is nidation which is the process of implanting the products of conception in the endometrium) and the formation of the placenta and the final stage is the growth and development of the products of conception until aterm (Manuaba 2013)

Pregnancy is divided into three trimesters, where the third trimester is the third trimester of pregnancy. The third trimester of pregnancy begins at the 27th week until a term (38-40 weeks). Physical discomfort and fetal movement often disturb the mother, increased urination, back pain, constipation and varicose veins are experienced by most women in the late stages of pregnancy (Siti Fauziah dan Sutejo 2012)

Pregnant women are encouraged to do pregnancy exercises during pregnancy to adapt to their physical and physiological changes were physical and psychological changes cause discomfort during pregnancy. Decreased sleep quality is an inconvenience that is often experienced by pregnant women, pregnancy exercise is a program intended for pregnant women in order to 
tighten the body system and prepare the muscles needed as an addition that must be experienced during pregnancy (Siti Fauziah dan Sutejo 2012)

Factors that affect pregnancy exercises are gestational age where pregnant exercise is approximately 16-38 weeks pregnant (Jannah, 2012). There is no bleeding in pregnancy or the pregnancy has entered the mid-trimester around the age of 20 weeks of gestation, because at this gestational age the placenta has been fully formed so that the possibility of a miscarriage is less likely. (Freddy Wagey 2011)

Musculoskeletal changes felt by pregnant women in the third trimester, the hormone progesterone and the hormone relaxing the connective tissue and muscles. This occurs maximally in the last week of pregnancy. This relaxation process provides an opportunity for the pelvis to increase its capacity in preparation for childbirth, the pubic bone softens like a joint, the sacrococcal joint loosens making the coccyx bone shift towards the back of the unstable hip joint. In pregnant women this causes back pain. A woman's posture gradually changes as the fetus enlarges in the abdomen so that to compensate for weight gain, the shoulders are pulled back and the bones are more curved, the spinal joints are more flexible, and can cause back pain in some women (Sari 2015)

The results of the study Lichayati, 2013 in Lamongan that pregnancy exercises need to be taught in the prenatal period to ensure the return of normal postnatal muscle shape quickly, the ability to push effectively during childbirth, especially reduce back pain during pregnancy.

The movements in pregnancy exercise can affect the quality of sleep of pregnant women. One of the movements of pregnancy exercise is the relaxation movement. Physiologically, relaxation exercises in pregnancy exercise will cause relaxation involving the parasympathetic nerves in the central nervous system. One of the functions of the parasympathetic nerves is the adrenaline hormone and epinephrine (stress hormone) and increases the secretion of the hormone noradrenaline or nor epinephrine (relaxing hormone) so that there is a decrease in anxiety and tension in pregnant women which causes pregnant women to relax (Wulandari 2006). It is explained that sleep provides two main physiological effects for the individual body, first is the effect on the nervous system and second for other functional systems of the body where the effect on the nervous system seems to be much more important because the nervous system takes a dominant role in the overall system that works in the individual's body.

According to (Bobak 2005), the need for sleep in pregnant women is that pregnant women take a nap during the day for approximately 2 hours and a night sleep of approximately 8 hours. Pregnant women should go to bed early and don't sleep too late because it has an impact on the health of the mother and fetus. Sleep quality is a condition in which the sleep that an individual undergoes produces freshness and fitness when awakened. Sleep quality includes quantitative aspects of sleep, such as sleep duration, sleep latency, as well as subjective aspects, such as deep sleep and rest. Sleep quality is the ability of each person to maintain a state of sleep and to get appropriate stages of REM and NREM sleep (Khasanah 2012). Sleep quality is not only assessed from qualitative aspects but also quantitative aspects such as length of sleep, time required to sleep and frequency of awakening from sleep, time required to fall asleep and frequency of awakening from sleep at night. In addition, subjective assessment of sleep should not be ignored, such as feeling satisfied and refreshed after waking up in the morning, feeling energized or tired when we wake up in the morning.

\section{MATERIALS \& METHODS}

This type of research is a preexperimental one group pretest and posttest with a research design using a quantitative approach. This research was conducted by 
giving a pretest (initial observation) before being given an intervention. After the intervention was given, then a posttest (final observation) was carried out. And the Wilcoxon signed rank test was conducted to determine the effect of pregnancy exercise on improving the sleep quality of pregnant women in Trimeter III. (Hidayat 2014)

\section{Statistical analysis}

Bivariate analysis to prove the research hypothesis. The bivariate analysis test in this study used the Paired-Samples T Test which was used to compare two groups or two samples that were paired with each other and if the normality test obtained data that was not normally distributed, the Wilcoxon test using SPSS was used, the basis for decision making Wilcoxon test if the Asymp sig value $<0.05$, then the hypothesis is accepted and if the Asymp sig value $>0.05$ then the hypothesis is rejected.

\section{RESULT}

\section{Normality Test}

Table 1: Normality Test
\begin{tabular}{|l|c|c|c|c|c|c|}
\hline & \multicolumn{2}{|c|}{ Kolmogorov-Smimov } & \multicolumn{3}{c|}{ Shapiro-wilk } \\
\hline & Statistic & df & Sig. & Statistic & df & Sig. \\
\hline Pretest.Sleep Quality &, 499 & 25 &, 000 &, 565 & 25 &, 000 \\
\hline Posttest. Sleep Quality &, 409 & 25 &, 000 &, 610 & 25 &, 000 \\
\hline
\end{tabular}

Based on Table 1. Normality test data on Shapiro Wilk the value of asymp.sig (2-tailed) $=0.00$ and $0.00<0.05$ then $\mathrm{Ha}$ is accepted, so normally distributed means that it does not meet the requirements for the next paired t-Test test. Next statistical test was the Wilcoxon signed ranks test

\section{Univariate Analysis}

Table 2: Average sleep quality of pregnant women in the third trimester before and after pregnancy exercise in the working area of the Ulaweng Health Centre

\begin{tabular}{|l|c|c|}
\hline \multicolumn{1}{|c|}{ Variable } & N & Mean \\
\hline Sleep Quality before Pregnancy Exercises & 25 & 1,72 \\
\hline Sleep Quality after Pregnancy Exercises & 25 & 1,36 \\
\hline
\end{tabular}

Based on Table 2, it can be seen that the average sleep quality of pregnant women in the third trimester before the intervention had a different mean value of sleep quality 1.72 and the average sleep quality after the intervention with pregnancy exercise became a mean value of 1.36, meaning there was an increase in the average of sleep quality of pregnant women in the third trimester after pregnancy exercise

Table 3: The Frequency before Pregnancy Exercises in the working area of the Ulaweng Health Centre

\begin{tabular}{|c|c|c|c|c|}
\hline & Frequensy & Percent & $\begin{array}{c}\text { Valid } \\
\text { Percent }\end{array}$ & $\begin{array}{c}\text { Cumulative } \\
\text { Percent }\end{array}$ \\
\hline Poor & 18 & 72 & 72 & 72 \\
\hline Good & 7 & 28 & 28 & 28 \\
\hline Total & $\mathbf{2 5}$ & $\mathbf{1 0 0}$ & $\mathbf{1 0 0}$ & $\mathbf{1 0 0}$ \\
\hline
\end{tabular}

Based on table 3 above, the frequency of changes that occur in third trimester pregnant women, where before doing pregnancy exercise there were 18 pregnant women who experienced poor sleep quality, and 7 pregnant women experienced good sleep quality

Table 4: The Frequency after Pregnancy Exercises in the working area of the Ulaweng Health Centre

\begin{tabular}{|c|c|c|c|c|}
\hline & Frequensy & Percent & $\begin{array}{c}\text { Valid } \\
\text { Percent }\end{array}$ & $\begin{array}{c}\text { Cumulative } \\
\text { Percent }\end{array}$ \\
\hline Poor & 9 & 36 & 36 & 36 \\
\hline Good & 16 & 64 & 64 & 64 \\
\hline Total & $\mathbf{2 5}$ & $\mathbf{1 0 0}$ & $\mathbf{1 0 0}$ & $\mathbf{1 0 0}$ \\
\hline
\end{tabular}


Based on table 4 above, the frequency changes that occur in third trimester pregnant women after pregnancy exercise increases sleep quality where 16 people have good sleep quality (64\%) and there are still 9 pregnant women with poor sleep quality (36\%)

\section{Bivariate Analysis}

\section{a. Test of wilcoxon Signed Ranks}

\begin{tabular}{|l|l|c|c|c|}
\hline \multicolumn{2}{|c|}{} & $\mathbf{N}$ & Mean Rank & Sum of Ranks \\
\hline Posttest Sleep Quality Pretest. Sleep Quality & Negative Ranks & $9^{\mathrm{a}}$ & 5,00 & 45.00 \\
\hline & Positive Ranks & $0^{\mathrm{b}}$ &, 00 &, 00 \\
\hline & Ties & $16^{\mathrm{c}}$ & & \\
\cline { 2 - 5 } & Total & $\mathbf{2 5}$ & \\
\hline \\
a. Post pregnancy exercises < Pre pregnancy exercises \\
b. Post pregnancy exercises > Pre pregnancy exercises \\
c. Post pregnancy exercises = Pre pregnancy exercises
\end{tabular}

b. Test statistic

\begin{tabular}{|l|c|}
\hline & $\begin{array}{c}\text { Posttest. Sleep Quality - } \\
\text { Pretest. Sleep Quality }\end{array}$ \\
\hline$Z$ & $-3,000^{\mathrm{b}}$ \\
\hline Asymp.Sig.(2-tailed) & 0,03 \\
\hline \multicolumn{2}{|c|}{ a. Wilcoxon Signed Ranks Test } \\
b. $\quad$ Based on positive ranks
\end{tabular}

Based on table 5 above, in the Wilcoxon signed ranks test and the sign test in the test statistics test the exact sig value. (2-tailed) and asymp.sig. (2-tailed) or $\mathrm{p}=$ $0.03<0.05$, which means that $\mathrm{HO}$ is significant and Ha is accepted. From the two variables, there are differences in the sleep quality of third trimester pregnant women who do not exercise during pregnancy and those who do pregnancy exercise in the working area of the Ulaweng Health Center in 2021).

\section{DISCUSSION}

Based on the results of the study, the number of samples was 25 pregnant women, before pregnancy exercise was carried out 7 pregnant women or $28 \%$ had good sleep quality and 18 people or $72 \%$ had sleep disorders, and after doing pregnancy exercise, there was an increase in sleep quality. 16 people (64\%) with good sleep quality and there are still pregnant women who have sleep disorders as many as 9 people (36\%) Based on the results of statistical tests, the Wilcoxon signed ranks test obtained an exact sig value. (2-tailed) and asymp. sig. (2-tailed) or $\mathrm{p}=0.03<0.05$ so it can be concluded that pregnancy exercise affects the sleep quality of pregnant women in the third trimester.
Pregnancy exercise is one of the activities in health services during pregnancy in Indonesia. The Ministry of Health requires a minimum service standard that contains 14 steps towards integrated and complete maternal protection. (Maryunani,Anik \& Yetty 2011)

Based on the facts and theory, it can be concluded that at the end of pregnancy pregnant women who do regular pregnancy exercises provide many benefits, one of the benefits obtained by gentle stretching during pregnancy can help relieve musculoskeletal discomfort in the mother. Viona pithaloka's research, 2020 states that pregnant women who take part in pregnancy exercise have better sleep quality.

Research conducted by (Nila Marwiyah 2018) states that pregnancy exercise activities can be an effort that can be made to improve sleep quality in pregnant women, this is also in line with research conducted by (Dewi Taurisiawati 2018) there are significant differences in the quality of pre-pregnancy sleep in pre-test and post-test for pregnant women in the third trimester where pregnant women who regularly do pregnancy exercises, the abdominal wall muscles will be stronger so that the elasticity of the abdominal wall muscles can also be maintained so that they 
can adapt to changes during pregnancy. In the study, some pregnant women after doing pregnancy exercise still experienced sleep disorder based on the results of interviews from several respondents and based on the theory that not only physical problems must be addressed to overcome sleep quality but the important thing is also related to internal stressors and external stressors which are basic needs for pregnant women is evident from the results of interviews with respondents saying that I have taken the steps of pregnancy exercise and do pregnancy exercises regularly but my sleep quality is still disturbed because of the many thoughts we think, one of which he put forward related to economic problems in the family. And based on the theory that in the third trimester of pregnancy where the fetus is growing so that it suppresses the bladder which is also one of the causes of pregnant women often waking up at night to urinate so that the quality of the mother's sleep is inadequate (Sari 2015)

\section{CONCLUSION}

Based on the results of the statistical test, the Wilcoxon signed ranks test obtained the exact sig value. (2-tailed) and asymp. sig. (2-tailed) or $p=0.03<0.05$ so it can be concluded that pregnancy exercise affects the sleep quality of pregnant women in the third trimester.

It is recommended to health workers, especially midwives, to conduct more indepth counseling, especially counseling about the importance of doing pregnancy exercise, especially in the third trimester of pregnancy to provide comfort to pregnant women and to prevent complications in pregnancy so as to reduce cases of maternal and infant mortality rates during pregnancy at Bone district.

\section{Acknowledgement: None}

Conflict of Interest: None

Source of Funding: None

Ethical Approval: Approved

\section{REFERENCES}

1. Bobak, L. 2005. Buku Ajar Keperawatan Maternitas. 4th ed. Jakarta: EGC.

2. Dewi Taurisiawati. 2018. "Hubungan Tingkat Kecemasan Dengan Kualitas Tidur Ibu Hamil Trimester III Di Puskesmas Jatinagor Kabupaten Sumedang.” Fakultas Ilmu Keperawatan Universitas Padjajaran Bandung.

3. Elisabeth Siwi Walyani. 2015. Asuhan Kebidanan Pada Kehamilan. Yogyakarta: Pustaka Baru Press.

4. Freddy Wagey. 2011. "Senam Hamil Meningkatkan Antioksidan Enzimatik, Kekuatan Otot Panggul, Kualitas Jasmani Dan Menurunkan Kerusakan Oksidatif Pada Wanita Hamil.” Denpasar: Universitas Udayana.

https://scholar.google.co.id/scholar?oi=bibs \&cluster $=17826764168975777167 \& b t n I=1$ \&hl=id.

5. Health, Ministry of. 2014. Profil Kesehatan Indonesia. Short Textbook of Preventive and Social Medicine. https://doi.org/10.5005/jp/books/11257_5.

6. Hidayat, Alimul. 2014. Metode Penelitian Keperwatan Dan Tekhnik Analisis Data. Jakarta: Salemba Medika.

7. Khasanah. 2012. "Kualitas Tidur Lansia Balai Rehabilitasi Sosial Mandiri.” Universitas Diponegoro.

8. Manuaba. 2013. Ilmu Kebidanan Penyakit Kandungan Dan KB. Jakarta: EGC.

9. Maryunani,Anik \& Yetty, s. 2011. Senam Hamil,Senam Nifas Dan Terapi Musik. Jakarta: TIM.

10. Nila Marwiyah. 2018. "Pengaruh Senam Hamil Terhadap Kualitas Tidur Ibu Hamil Trimester II Dan III Di Kelurahan Margaluyu Wilayah Kerja Puskesmas Kasemen.” Faletehan Health Journal 5 (3). https://doi.org/10.33746/fjh.v5i3.34.

11. Okun, Michele L., Christine Dunkel Schetter, and Laura M. Glynn. 2011. "Poor Sleep Quality Is Associated with Preterm Birth.” Sleep 34 (11): 1493-98. https://doi.org/10.5665/sleep.1384.

12. Pithaloka, Vinona. 2020. "Pengaruh Senam Hamil Terhadap Kualitas Tidur Ibu Hamil Trimester III." Jurnal Kebidanan: Jurnal Medical Science Ilmu Kesehatan Akademi Kebidanan Budi Mulia Palembang 10 (2): 38-44. https://doi.org/10.35325/kebidanan.v10i2.23 8. 
Indryani et.al. The effect of pregnancy exercises on the sleep quality of pregnant women in the third trimester of Ulaweng Health Center work area, Bone Regency

13. Sari, Anggrita. 2015. Asuhan Kebidanan Pada Kehamilan. Bogor: In Media.

14. Siti Fauziah dan Sutejo. 2012. Keperawatan Maternitas Kehamilan. Jakarta: Kencana Pernada Media.

15. South Sulawesi Provincial Health Office. 2015. "Profil Kesehatan Provinsi Sulawesi Selatan.” Profil Kesehatan Provinsi Sulawesi Selatan, 111.

16. Venkata C. and Venkatashiah S. B. 2009. "Sleep Disordered Breathing During Pregnancy.” The Journal of the American Board of Family Medicine 22 (2): 158-68.
17. WHO. 2017. "World Health Statistic."

18. Wulandari, Primatia Yogi. 2006. "Efektivitas Senam Hamil Sebagai Pelayanan Prenatal Dalam.” Insan 8 (2): 136-45.

How to cite this article: Indryani, Mustar. The effect of pregnancy exercises on the sleep quality of pregnant women in the third trimester of Ulaweng Health Center work area, Bone Regency. International Journal of Science \& Healthcare Research. 2021; 6(4): 198-204. DOI: https://doi.org/10.52403/ijshr.20211028 